\title{
Optimization of Chemical Composition and Microstructure of Iron Ore Sinter for Low-temperature Drip of Molten Iron with High Permeability
}

\author{
Kenichi HIGUCHI, Masaaki NAITO, Masanori NAKANO and Yasushi TAKAMOTO \\ Environment \& Process Technology Center, Nippon Steel Corporation, Futtsu, Chiba 293-8511 Japan.
}

(Received on April 30, 2004; accepted in final form on July 5, 2004)

\begin{abstract}
To discuss sinter condition for lowering dripping temperature of molten iron and enhancing reducibility, reduction behavior of sinter samples with extensive range of chemical composition was measured with reduction test under load. Basicity was found to have dominant influence on dripping temperature and should be in the range between 1.0 and 1.5. A further decrease in dripping temperature was achieved by decreasing $\mathrm{Al}_{2} \mathrm{O}_{3}$ content and increasing $\mathrm{MgO}$ content in sinter, which was related with low liquidus temperature, low viscosity and fast smelting-reduction of slag containing low FeO content. In contrast, reducibility and mineralogy of sinter influenced softening-melting behavior as well. Increasing fine pores could improve softening-melting behavior as a result of enhancing reducibility. Finally optimized sinter, containing 1.0-1.5 basicity, low $\mathrm{Al}_{2} \mathrm{O}_{3}$ and high $\mathrm{MgO}$ content was proposed. This chemical composition of sinter could lower dripping temperature by $80^{\circ} \mathrm{C}$ with fairly high permeability of sinter layer compared to conventional sinter. Possibility of the further improvement of softening-melting behavior at a constant chemical composition with controlling sinter mineralogy was discussed.
\end{abstract}

KEY WORDS: agglomeration; iron ore sinter; reduction; dripping; softening-melting; porosity; microstructure.

\section{Introduction}

In Japan, an innovative compact blast furnace has been discussed to lower energy consumption with countering the deterioration of quality of iron ore resources in ironmaking process. One of the dominant factors controlling the furnace is lowering the furnace temperature with maintaining stable operation. In particular, decreasing dripping temperature of molten iron and enhancing reducibility of iron ore sinter are necessary and those may be deeply associated with reduction behavior of iron ore sinter.

Since the discovery of cohesive zone in quenched blast furnaces, many investigations have been explored to evaluate the behavior of sinter during reduction at high temperatures. Reduction behavior of sinter is determined namely by three factors, chemical composition, pore structure and microstructure (constituting minerals). These factors interact each other and are determined by raw material conditions and operational conditions in sintering process.

Concerning the first factor, chemical composition of sinter, it was reported that basicity $\left(\mathrm{CaO} / \mathrm{SiO}_{2}\right)$ of sinter increases dripping temperature, ${ }^{*,-5}$ resulting in a high amount of residue materials in crucibles even at high temperatures. ${ }^{5-7)}$ The increase in softening-melting temperature with basicity was found as well. ${ }^{8)}$ Permeability of sinter layer during reduction is affected by both softening-melting and dripping behavior and improved by increasing basicity. $\left.{ }^{9}\right)$ On the other hand, some investigations showed the inverse influence of basicity on the permeability. ${ }^{10)}$ Although it was reported that $\mathrm{Al}_{2} \mathrm{O}_{3}$ in sinter had harmful effect on blast furnace operation, ${ }^{11)}$ the information of the influence of $\mathrm{Al}_{2} \mathrm{O}_{3}$ on softening-melting and dripping behavior is limited. ${ }^{7,12)}$ The influence of $\mathrm{MgO}$ on dripping temperature seems complex. An increase in dripping temperature with $\mathrm{MgO}$ content in sinter was reported, ${ }^{9,13)}$ whereas Barnada ${ }^{5)}$ claimed the inverse influence of $\mathrm{MgO}$ at basicity above 1.6. Ritz et al. ${ }^{14)}$ explained that the influence of $\mathrm{MgO}$ was varied by the reduction condition. In contrast, there are many investigations reporting an increase in softening-melting temperature with $\mathrm{MgO}{ }^{4,8,15,16)}$ One of the reasons for the disparity of results among the past investigations on chemical composition of sinter seems to be a small estimated range and the influence in extensive range is still unknown.

The second factor, pore structure of sinter has large influence on softening-melting behavior via their reduction rate and intrusion of melt during reduction. Porosity itself enhances reduction as a result of the increase in surface reduction area and in efficiency of gas diffusion in indirect reduction below $1000^{\circ} \mathrm{C}$.

The third factor, sinter mineralogy caused by ore charac-

* Notification: As the word expressing the same phenomenon is different among past papers, authors defined the temperature at which the first drip takes place as dripping temperature and the temperature at which pressure drop starts to increase as softening-melting temperature in the present study. 
teristics such as grain size of hematite and distribution of gangue minerals seems to have the influence on reduction behavior via forming microstructure and pore structure during reduction even at a constant chemical composition of sinter. However the information on sinter mineralogy on high-temperature reduction is still limited. ${ }^{17)}$

In the present paper, reduction tests under load of sinter with extensive range of chemical composition have been performed and optimization of chemical composition, pore structure and microstructure was discussed to attain suitable properties of sinter for the innovative blast furnace. In particular, conditions for low-temperature drip of molten iron has been focused.

\section{Experimental Methods}

\subsection{Sinter and Pellets}

Sinter samples with different chemical compositions (basicity $=1.2-2.6, \mathrm{SiO}_{2}=3.0-6.8 \mathrm{mass}^{2}, \mathrm{Al}_{2} \mathrm{O}_{3}=1.1-3.2$ mass $\%, \mathrm{MgO}=0.2-2.5$ mass $\%$ ) were produced by using a pot simulator whose diameter was $30 \mathrm{~cm}$ and $60 \mathrm{~cm}$ in bed height. Blending conditions of iron ores and fluxes were changes to attain desired chemical compositions. Table 1 shows chemical compositions of iron ores and fluxes used in the present study. Ore A is Brazilian soft hematite ore and Ore B is Brazilian hard hematite ore. Ore $\mathrm{C}$ is Australian soft hematite ore. Ore D is Indian soft hematite ore. Ore E and Ore F are Australian Pisolitic limonite ores. Coke content in a raw mixture was adjusted to maintain sufficient value of sinter strength for blast furnaces, above $70 \%$ in $+5 \mathrm{~mm}$ fraction after dropping a sinter cake from a height of $2 \mathrm{~m}, 5$ times.

For comparison, artificial pellets, having more homogeneous structure than sinter, with different chemical composition $\left(\right.$ basicity $=0.0-1.9, \quad \mathrm{SiO}_{2}=1.3-4.4 \operatorname{mass} \%, \mathrm{Al}_{2} \mathrm{O}_{3}=$ $0.4-2.4$ mass $\%, \mathrm{MgO}=0.0-1.7$ mass $\%$ ) were tested to approach more fundamental influence of chemical composition. Pellets were produced from Brazilian hematite pellet feed whose $\mathrm{SiO}_{2}$ and $\mathrm{Al}_{2} \mathrm{O}_{3}$ content were 1.68 mass $\%$ and 0.67 mass \%, respectively. Reagent chemical of $\mathrm{CaCO}_{3}$, $\mathrm{Al}_{2} \mathrm{O}_{3}, \mathrm{SiO}_{2}, \mathrm{MgO}$ were mixed into the ore to attain desired chemical compositions. A green pellet 10 to $15 \mathrm{~mm}$ in diameter was obtained by using small-scale pelletizer and subsequently sintered for $24 \mathrm{~h}$ in air at $1000^{\circ} \mathrm{C}$ following for $1 \mathrm{~h}$ in air at $1350^{\circ} \mathrm{C}$.

Total porosity of product sinter and pellets was measured by using PAC method, developed by Nippon Steel. ${ }^{18)}$ Pore structure of samples crushed into 2 to $3 \mathrm{~mm}$ in diameter was measured by using mercury-intruding porosimetry. Microstructure was observed with optical microscopy and quantified with image analysis. Some of constituting mineral phases were identified by using EPMA.

\subsection{Reduction Tests under Load}

Reduction behavior of sinter and pellets 10 to $15 \mathrm{~mm}$ in diameter was measured by using an apparatus for reduction test under load with adiabatic control shown in Fig. 1. ${ }^{19)}$ Reduction condition is listed in Table 2 as Test 1 . Figure 2 shows a schematic diagram of reduction behavior of sinter and pellets at high temperatures above $1000^{\circ} \mathrm{C}$ and influencing factors.
Table 1. Chemical compositions of raw materials used in the present study.

\begin{tabular}{|c|c|c|c|c|c|c|c|}
\hline & \multirow{2}{*}{ Brand } & \multirow{2}{*}{ Particle size } & \multicolumn{5}{|c|}{ Chemical composition (mass $\%$ ) } \\
\hline & & & T.Fe & $\mathrm{SiO}_{2}$ & $\mathrm{Al}_{2} \mathrm{O}_{3}$ & $\mathrm{MgO}$ & $\mathrm{LOI}^{*}$ \\
\hline \multirow{12}{*}{$\begin{array}{l}\text { Iron } \\
\text { ores }\end{array}$} & \multirow{2}{*}{ Ore A } & $-7 \mathrm{~mm}$ & 67.3 & 0.53 & 0.87 & \multirow{12}{*}{ Trace } & 1.41 \\
\hline & & $2.8-4.75 \mathrm{~mm}$ & 67.7 & 0.44 & 0.68 & & 1.17 \\
\hline & \multirow{2}{*}{ Ore B } & $-7 \mathrm{~mm}$ & 65.3 & 4.06 & 1.02 & & 1.07 \\
\hline & & $2.8-4.75 \mathrm{~mm}$ & 66.8 & 2.01 & 0.90 & & 1.06 \\
\hline & \multirow{2}{*}{ Ore C } & $-7 \mathrm{~mm}$ & 63.0 & 3.89 & 2.11 & & 2.91 \\
\hline & & $2.8-4.75 \mathrm{~mm}$ & 63.9 & 3.16 & 1.77 & & 2.76 \\
\hline & \multirow{2}{*}{ Ore D } & $-7 \mathrm{~mm}$ & 62.5 & 3.08 & 1.83 & & 3.99 \\
\hline & & $2.8-4.75 \mathrm{~mm}$ & 60.2 & 2.90 & 2.51 & & 6.51 \\
\hline & \multirow{2}{*}{ Ore $\mathrm{E}$} & $-7 \mathrm{~mm}$ & 58.5 & 4.75 & 1.09 & & 8.40 \\
\hline & & $2.8-4.75 \mathrm{~mm}$ & 58.6 & 5.05 & 0.95 & & 8.32 \\
\hline & \multirow{2}{*}{ Ore $\mathrm{F}$} & $-7 \mathrm{~mm}$ & 57.0 & 5.51 & 2.65 & & 7.63 \\
\hline & & $2.8-4.75 \mathrm{~mm}$ & 57.5 & 4.99 & 2.47 & & 7.84 \\
\hline \multicolumn{2}{|c|}{ Limestone } & $-7 \mathrm{~mm}$ & 2.5 & 0.3 & 0.1 & 0.4 & 43.8 \\
\hline \multicolumn{2}{|c|}{ Serpentine } & $-7 \mathrm{~mm}$ & 6.1 & 38.1 & 0.6 & 36.6 & 12.5 \\
\hline \multicolumn{2}{|c|}{ Silica sand } & $-7 \mathrm{~mm}$ & 1.9 & 91.2 & 2.8 & 1.0 & 1.1 \\
\hline
\end{tabular}

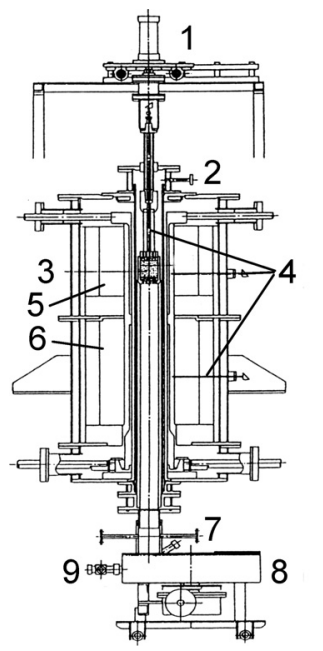

1. Loading apparatus

2. Gas outlet

3. Sample (inner diameter; 85mm)

4. Thermo-couples

5. Upper furnace

6. Lower furnace

7. Gas inlet

8. Drip receiver

9. Drip detector

Fig. 1. Schematic diagram of apparatus of reduction test under load.

Table 2. Reduction test conditions.

\begin{tabular}{|cc|c|c|}
\hline & & $\begin{array}{c}\text { Test 1 } \\
\text { Reduction test under load }\end{array}$ & $\begin{array}{c}\text { Test 2 } \\
\text { Small-scale } \\
\text { reduction test }\end{array}$ \\
\hline Reduction temperature $\quad\left({ }^{\circ} \mathrm{C}\right)$ & $800-1600$ & $1000-1200$ \\
\hline Heating-up rate $\left({ }^{\circ} \mathrm{C} / \mathrm{min}\right)$ & $\begin{array}{c}10\left(800-1000^{\circ} \mathrm{C}\right) \\
5\left(1000-1600^{\circ} \mathrm{C}\right)\end{array}$ & 7 \\
\hline Gas flow rate $(\mathrm{N} / \mathrm{min})$ & 34 & 5 \\
\hline Superficial gas velocity & $(\mathrm{cm} / \mathrm{s})$ & 10 & 4 \\
\hline Load & $(\mathrm{kPa})$ & 98 & 98 \\
\hline Reduction gas & $\mathrm{CO} 29.4 \%-\mathrm{H}_{2} 3.6 \%-\mathrm{N}_{2} 67 \%$ & $\mathrm{CO} 30 \%-\mathrm{N}_{2} 70 \%$ \\
\hline Sample weight & $\begin{array}{c}490-900 \\
(70 \mathrm{~mm} \text { bed height })\end{array}$ & 20 \\
\hline Sample size & $10-15$ & $3-5$ \\
\hline Pre-reduction degree & $(\%)$ & 0 & 33 \\
\hline
\end{tabular}

Based on the result of direct observations, ${ }^{20)}$ reduction behavior of sinter is described as follows. Reduction rate shows a retardation at a temperature near $1100^{\circ} \mathrm{C}$ as a result of softening led from local primary melt formation. In the case of reduction of pellet, metal-shell formation significantly inhibits gas diffusion. With increasing in amount of melt, ore layer turns into massive structure resulting in an increase in gas flow resistance. Simultaneously melt starts to exude and smelting reduction takes place. As the reduction behavior is complex, following indices were chosen in the present study. As an index for reducibility before prima- 
ry melt formation, R1000 (reduction degree at $1000^{\circ} \mathrm{C}$ ) was chosen. For softening-melting behavior, Ts (Temperature at which pressure drop increased up to 2.0 $\mathrm{kPa}$ ) was measured. RTs (Reduction degree at Ts) was measured as a combined index representing both reduction and softening-melting. Ts and RTs are linking each other. Td (Dripping temperature) was defined as the temperature at which melt receiver detects the first drip from graphite crucible. MDR (Metal-drip ratio) was calculated from total weight of dripped metal during tests. $\mathrm{S}$ value, an accumulative value of pressure drop, ${ }^{21)}$ was used for evaluating permeability of sinter layer during reduction. Ts is related with nature of formed slag, i.e. Solidus temperature and fluidity

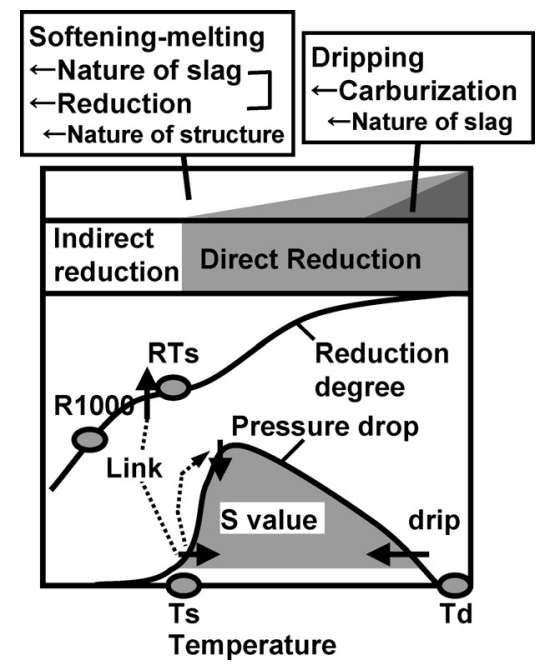

Fig. 2. Schematic diagram of measured indices in reduction test and influencing factors.
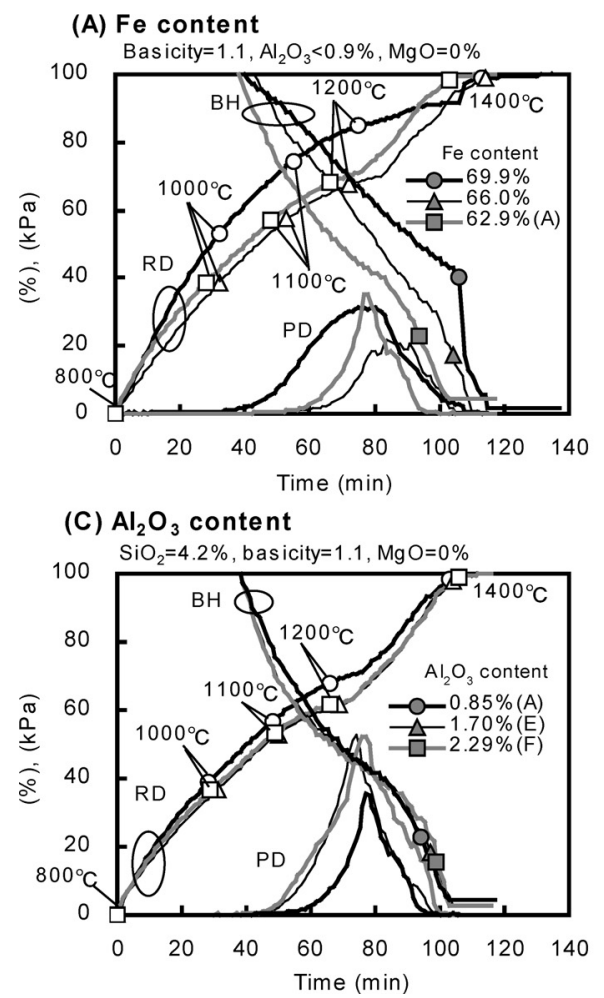

of melt, and with nature of sinter structure, i.e. pore structure and reducibility of constituting mineral phases as well. On the other hand, Td much depends on the nature of slag because melt plays a major role in carburization of reduced iron.

\subsection{Small-scale Reduction Tests}

To clarify the influence of sinter mineralogy caused by properties of natural ores, small-scale reduction tests of sintered samples were performed. Pseudo-particles were produced by hand-granulation of a mixture consisting of nuclei, natural iron ores sieved into $2.8-4.75 \mathrm{~mm}$, and limestone whose diameter was smaller than $0.125 \mathrm{~mm}$ in a constant mass ratio $(\mathrm{CaO} / \mathrm{Ore}=0.1)$. Granules were heated in air stream by using an electric furnace. Heating condition was demonstrated the plant condition and the maximum temperature was fixed at $1275^{\circ} \mathrm{C}$. After sintering, samples were crushed into particles 3 to $5 \mathrm{~mm}$ in diameter.

To demonstrate the reduction after the thermal reserve zone, reduction tests were conducted by using a small-scale reduction apparatus under load in the condition listed in Table 2 as Test 2. Sintered samples were pre-reduced up to wustite stage by using $\mathrm{CO} 50 \%-\mathrm{CO}_{2} 50 \%$ gas at $1000^{\circ} \mathrm{C}$ for $4 \mathrm{~h}$. R1200 (reduction degree at $1200^{\circ} \mathrm{C}$ ) was measured. To take account properties of residual ores in sintered ore structure, natural ores without assimilation with $\mathrm{CaO}$ were tested as well.

\section{Results}

Figure 3 shows the overview of measurement results, representing the influence of $\mathrm{Fe}$ content at a constant basici-
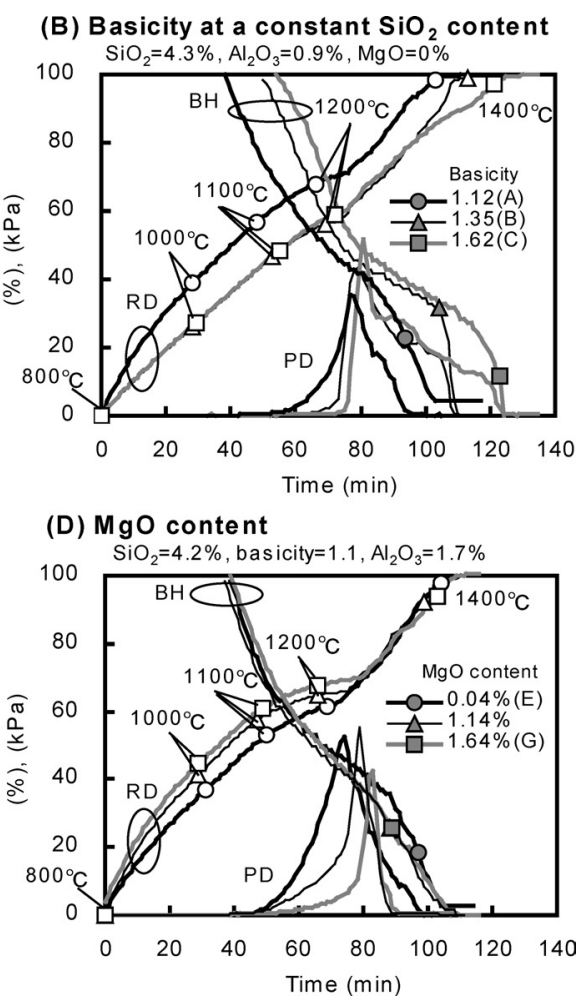

Fig. 3. Overview of measurement results of pellets showing the influence of (A) Fe content, (B) Basicity at a constant $\mathrm{SiO}_{2}$ content, (C) $\mathrm{Al}_{2} \mathrm{O}_{3}$ content and (D) $\mathrm{MgO}$ content on reduction behavior under load. $\mathrm{RD}, \mathrm{BH}$ and $\mathrm{PD}$ are Reduction degree, bed height and pressure drop, respectively. Closed keys represent the first dripping. A to $\mathrm{G}$ are corresponding to pellets shown in Fig. 10 and Table 4. 
ty of 1.1 (A), of basicity at 4.3 mass $\% \mathrm{SiO}_{2}$ content (B), of $\mathrm{Al}_{2} \mathrm{O}_{3}$ content $(\mathrm{C})$ and of $\mathrm{MgO}$ content (D). Pure hematite pellet showed an increase in pressure drop at $1020^{\circ} \mathrm{C}$ despite no melt formation at this temperature, which was caused by swelling. Detailed analysis of the results on individual reduction behavior, i.e. dripping, softening-melting and permeability were described in the following chapters.

\subsection{Dripping Behavior}

Figure 4 shows results of $\mathrm{Td}$ as a function of basicity of sinter and pellets. In all experiments, the first dripped material was molten iron and subsequently the drip of molten slag accompanied with molten iron was found during heating up to $1600^{\circ} \mathrm{C}$. It was clearly shown that basicity of slag had dominant influence on dripping behavior. Td was found to be a minimum in the basicity range of 1.0-1.1, agreed with the result of extensive range evaluation by Narita et

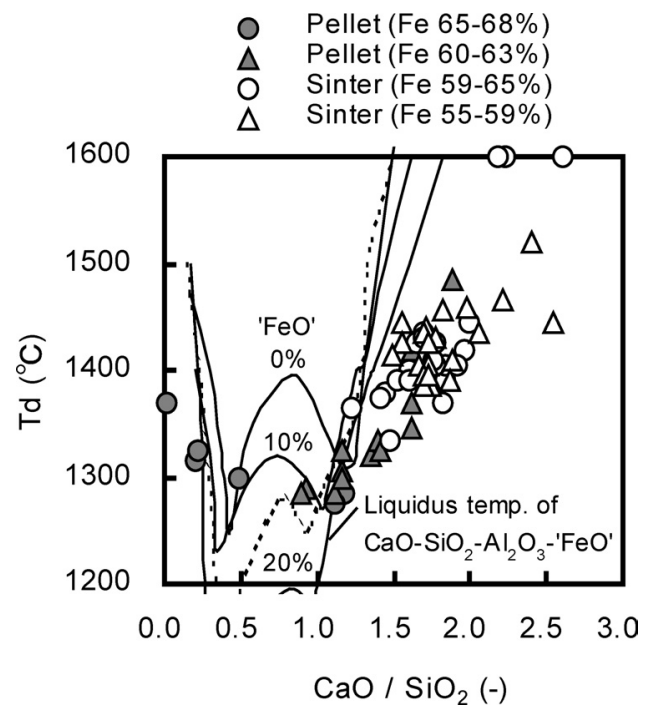

Fig. 4. Changes in $\mathrm{Td}$ with basicity of sinter and pellets. Solid curves are estimated liquidus temperatures of $\mathrm{CaO}-\mathrm{SiO}_{2}-$ $\mathrm{Al}_{2} \mathrm{O}_{3}-$ ' $\mathrm{FeO}$ ' slag in a constant $\mathrm{Al}_{2} \mathrm{O}_{3}$ content. ${ }^{22)} \mathrm{A}$ dotted curve is estimated liquidus temperatures of $\mathrm{CaO}-\mathrm{SiO}_{2}-$ $\mathrm{Al}_{2} \mathrm{O}_{3}-10$ mass \% 'FeO' slag. ${ }^{23)}$ $a l^{2)}$ MDR tended to decrease with basicity (see Table 4 Pellet A to D), as similar to the results of past investigations. ${ }^{5-7)}$ The influence of Fe content in sinter and pallets representing the gangue content was rather small.

Many investigations reported the correlation between liquidus temperature of gangue slag without ' $\mathrm{FeO}$ ' and dripping temperature. ${ }^{4,9)}$ Reduction degree at primary dripping of molten iron was at least $93 \%$ for sinter and $76 \%$ for pellets. Assuming that iron oxide at this reduction degree existed as ' $\mathrm{FeO}$ ' in melt and initial total gangue content in sinter and pellets was 15 mass\%, ' $\mathrm{FeO}$ ' content in $\mathrm{CaO}$ $\mathrm{SiO}_{2}-\mathrm{Al}_{2} \mathrm{O}_{3}-\mathrm{MgO}-$ ' $\mathrm{FeO}$ ' slag would 35 mass $\%$ for sinter and 65 mass \% for pellets, respectively. Dripping behavior therefore must relate with evolution process and properties of melt containing ' $\mathrm{FeO}$ '. Estimated liquidus temperatures of $\mathrm{CaO}-\mathrm{SiO}_{2}-\mathrm{Al}_{2} \mathrm{O}_{3}-{ }^{\prime} \mathrm{FeO}$ ' slag with $0.12 \mathrm{Al}_{2} \mathrm{O}_{3} /(\mathrm{CaO}+$ $\left.\mathrm{SiO}_{2}\right)$ ratio $^{22,23)}$ as a function of basicity were shown in Fig. 4. The relationship between $\mathrm{Td}$ and the estimated liquidus temperatures will be discussed in the following chapter.

Figure 5 shows the influences of $\mathrm{Al}_{2} \mathrm{O}_{3}$ and $\mathrm{MgO}$ in sinter and pellets with a constant basicity. In both sinter and pellets, the influence of $\mathrm{Al}_{2} \mathrm{O}_{3}$ was found to vary with ba-

Table 3. Measurement results of chemical composition of mineral phases in quenched sinter sample during reduction at $1200^{\circ} \mathrm{C}$ (Unit mass\%). E: Eutectic structure bearing fine wustite grains, $\mathrm{S}$ : Slag, $\mathrm{C}_{2} \mathrm{~S}$ : $2 \mathrm{CaO} \cdot \mathrm{SiO}_{2}, \mathrm{CS}: \mathrm{CaO} \cdot \mathrm{SiO}_{2}, \mathrm{~W}$ : Wustite.

\begin{tabular}{|c|c|c|c|c|c|c|c|}
\hline Portion no. & $\mathrm{FeO}$ & $\mathrm{CaO}$ & $\mathrm{SiO}_{2}$ & $\mathrm{Al}_{2} \mathrm{O}_{3}$ & $\mathrm{MgO}$ & $\mathrm{C} / \mathrm{S}$ & $\begin{array}{c}\text { Identified } \\
\text { phase }\end{array}$ \\
\hline 1 & 32.3 & 28.6 & 26.2 & 11.9 & 0.9 & 1.1 & $\mathrm{E}$ \\
\hline 2 & 6.8 & 41.2 & 22.9 & 28.2 & 0.9 & 1.8 & $\mathrm{~S}$ \\
\hline 3 & 2.2 & 66.6 & 31.0 & Trace & Trace & 2.1 & $\mathrm{C}_{2} \mathrm{~S}$ \\
\hline 4 & 1.5 & 67.4 & 31.0 & Trace & Trace & 2.2 & $\mathrm{C}_{2} \mathrm{~S}$ \\
\hline 5 & 1.8 & 67.6 & 30.4 & Trace & Trace & 2.2 & $\mathrm{C}_{2} \mathrm{~S}$ \\
\hline 6 & 2.1 & 51.8 & 46.0 & Trace & Trace & 1.1 & $\mathrm{CS}$ \\
\hline 7 & 3.1 & 50.6 & 46.2 & Trace & Trace & 1.1 & $\mathrm{CS}$ \\
\hline 8 & 2.5 & 52.6 & 44.8 & Trace & Trace & 1.2 & $\mathrm{CS}$ \\
\hline 9 & 96.5 & 0.5 & Trace & 0.4 & 2.6 & - & W \\
\hline 10 & 96.8 & 0.4 & Trace & 0.3 & 2.4 & - & W \\
\hline 11 & 96.9 & 0.6 & Trace & 0.4 & 2.1 & - & W \\
\hline 12 & 96.4 & 0.7 & Trace & 0.4 & 2.5 & - & W \\
\hline
\end{tabular}

Table 4. Measurement results of pellets and sinter.

\begin{tabular}{|c|c|c|c|c|c|c|c|c|c|c|c|}
\hline \multirow{2}{*}{\multicolumn{3}{|c|}{ Sample }} & \multicolumn{7}{|c|}{ Pellet } & \multicolumn{2}{|c|}{ Sinter } \\
\hline & & & $A$ & $B$ & $\mathrm{C}$ & $\mathrm{D}$ & $E$ & $\mathrm{~F}$ & $\mathrm{G}$ & S1 & $\mathrm{S} 2$ \\
\hline \multirow{6}{*}{ 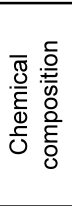 } & T.Fe & (mass $\%)$ & 62.9 & 62.1 & 61.3 & 60.4 & 62.4 & 62.0 & 61.3 & 62.7 & 57.7 \\
\hline & $\mathrm{C} / \mathrm{S}$ & $(-)$ & 1.12 & 1.35 & 1.62 & 1.88 & 1.16 & 1.17 & 1.16 & 1.44 & 1.83 \\
\hline & $\mathrm{SiO}_{2}$ & (mass $\%)$ & 4.31 & 4.37 & 4.38 & 4.39 & 4.17 & 4.16 & 4.18 & 3.61 & 4.93 \\
\hline & $\mathrm{Al}_{2} \mathrm{O}_{3}$ & (mass\%) & 0.85 & 0.87 & 0.88 & 0.99 & 1.70 & 2.29 & 1.66 & 0.96 & 1.72 \\
\hline & $\mathrm{MgO}$ & (mass \%) & 0.04 & 0.04 & 0.04 & 0.04 & 0.04 & 0.04 & 1.64 & 1.13 & 0.97 \\
\hline & $\mathrm{FeO}$ & (mass $\%)$ & 0.15 & 0.06 & 0.35 & 0.41 & 2.88 & 3.98 & 8.90 & 9.60 & 4.51 \\
\hline \multirow{4}{*}{ 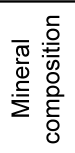 } & Hematite & (area\%) & 61 & 71 & 47 & 69 & 55 & 59 & 37 & 51 & 28 \\
\hline & Magnetite & (area\%) & 0 & 0 & 0 & 0 & 18 & 18 & 29 & 23 & 20 \\
\hline & SFCA & (area\%) & 5 & 16 & 40 & 21 & 14 & 12 & 20 & 20 & 46 \\
\hline & Glassy silicate & (area\%) & 34 & 13 & 13 & 10 & 13 & 11 & 14 & 6 & 7 \\
\hline \multirow{2}{*}{$\begin{array}{l}\text { 종 } \\
\text { 음 } \\
0\end{array}$} & Total porosity & $(\%)$ & 31.6 & 21.2 & 21.9 & 20.9 & 30.1 & 29.1 & 32.3 & 54.5 & 42.2 \\
\hline & $\begin{array}{l}-15 \mu \mathrm{m} \\
\text { porosity }\end{array}$ & (\%) & 7.6 & 3.8 & 8.3 & 7.5 & 4.3 & 4.3 & 4.3 & 13.0 & 13.3 \\
\hline \multirow{6}{*}{ 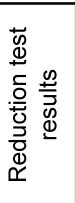 } & $\mathrm{Td}$ & $\left({ }^{\circ} \mathrm{C}\right)$ & 1285 & 1320 & 1420 & 1485 & 1305 & 1325 & 1300 & 1380 & 1457 \\
\hline & MDR & $(\%)$ & 97 & 89 & 77 & 58 & 94 & 89 & 89 & 90 & 53 \\
\hline & S value & $(\mathrm{KPa} \cdot \mathrm{min})$ & 459 & 804 & 920 & 1265 & 896 & 1140 & 243 & 69 & 717 \\
\hline & Ts & $\left({ }^{\circ} \mathrm{C}\right)$ & 1150 & 1200 & 1250 & 1250 & 1090 & 1090 & 1115 & 1258 & 1236 \\
\hline & RTs & $(\%)$ & 62.0 & 55.0 & 58.0 & 58.0 & 50.0 & 49.0 & 60.0 & 72.6 & 78.0 \\
\hline & R1000 & $(\%)$ & 40.4 & 32.3 & 35.1 & 34.5 & 41.9 & 41.7 & 47.8 & 34.5 & 35.1 \\
\hline
\end{tabular}




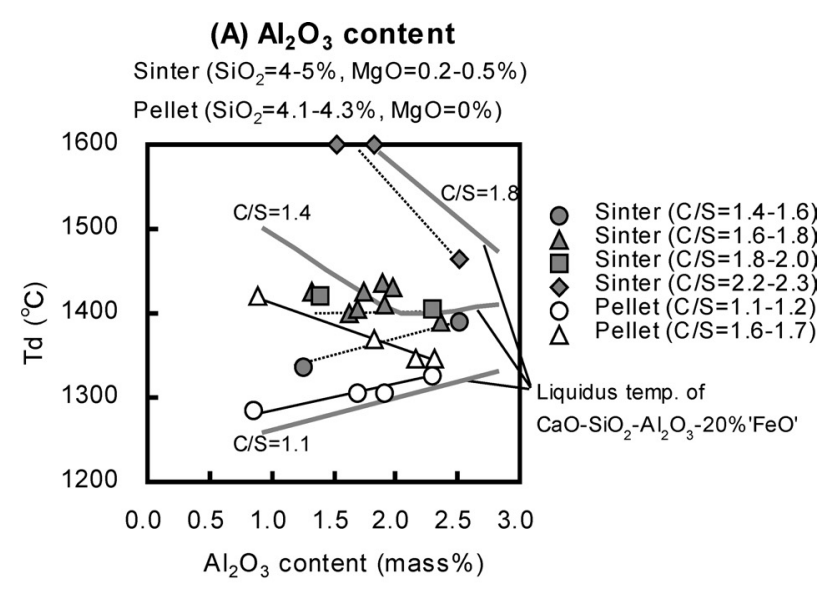

(B) MgO content

Sinter $\left(\mathrm{SiO}_{2}=4-6 \%, \mathrm{Al}_{2} \mathrm{O}_{3}=1.8-2.2 \%\right)$

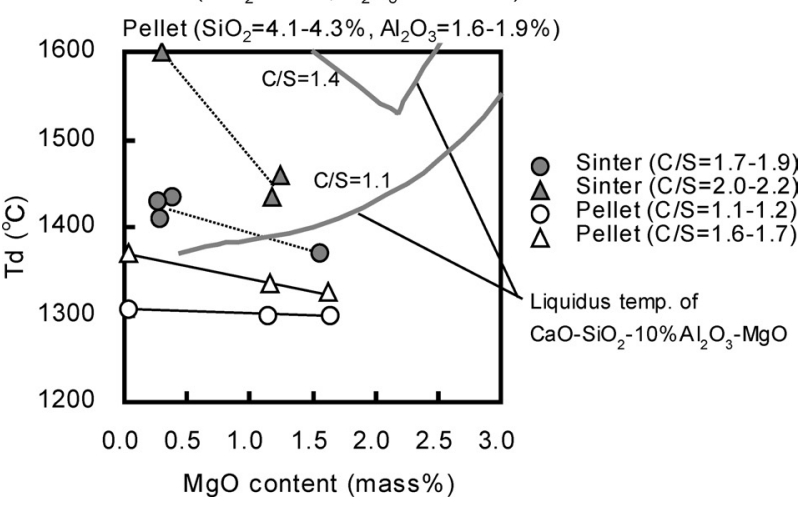

Fig. 5. Changes in $\mathrm{Td}$ with (A) $\mathrm{Al}_{2} \mathrm{O}_{3}$ and (B) $\mathrm{MgO}$ contents in sinter and pellets. Estimated liquidus temperatures ${ }^{22)}$ of $\mathrm{CaO}-\mathrm{SiO}_{2}-\mathrm{Al}_{2} \mathrm{O}_{3}-20$ mass\% ' $\mathrm{FeO}$ ' slag and of $\mathrm{CaO}-$ $\mathrm{SiO}_{2}-10$ mass $\% \mathrm{Al}_{2} \mathrm{O}_{3}-\mathrm{MgO}$ slag at a constant basicity were shown in (A) and (B), respectively. $\mathrm{C} / \mathrm{S}$ is basicity.

sicity condition. At lower basicity less than $1.6, \mathrm{Al}_{2} \mathrm{O}_{3}$ increased $\mathrm{Td}$, whereas it decreased at higher basicity. $\mathrm{MgO}$ decreased $\mathrm{Td}$ particularly at high basicity. $\mathrm{As} \mathrm{MgO}$ content in sinter and pellets was small, estimated liquidus temperatures of $\mathrm{CaO}-\mathrm{SiO}_{2}-\mathrm{Al}_{2} \mathrm{O}_{3}-20$ mass $\% \mathrm{FeO}$ slag at a constant basicity were shown in Fig. 5(A). Concerning the influence of $\mathrm{MgO}$, the information of phase diagram of $\mathrm{CaO}-\mathrm{SiO}_{2}-$ $\mathrm{Al}_{2} \mathrm{O}_{3}-\mathrm{MgO}-{ }^{-} \mathrm{FeO}$ ' slag is still unknown. Therefore estimated liquidus temperature of $\mathrm{CaO}-\mathrm{SiO}_{2}-10$ mass $\% \mathrm{Al}_{2} \mathrm{O}_{3}-$ $\mathrm{MgO}$ slag was shown in Fig. 5(B) for a reference. In both cases, total gangue content in sinter was fixed at 15 mass $\%$. The relationship between $\mathrm{Td}$ and the estimated liquidus temperatures will be discussed in the following chapter.

\subsection{Softening-Melting Behavior}

Figure 6 shows relationship between Ts and basicity of sinter and pellets. The influence of basicity on Ts was rather small compared to that on $\mathrm{Td}$ because softeningmelting behavior is influenced by reduction degree depending on physical structure as well. Nevertheless the low Ts at basicity from 0.5 to 1.0 was observed. Many investigations pointed out that softening-melting behavior was influenced by primary melt formation during reduction and could be estimated by solidus temperature. ${ }^{15,24)}$ Considering that RTs ranged $60-90 \%$ for sinter and $40-65 \%$ for pellets in the present study, ' $\mathrm{FeO}$ ' content in bulk oxide exclusive reduced iron would be briefly estimated as $40-70$ mass $\%$ for

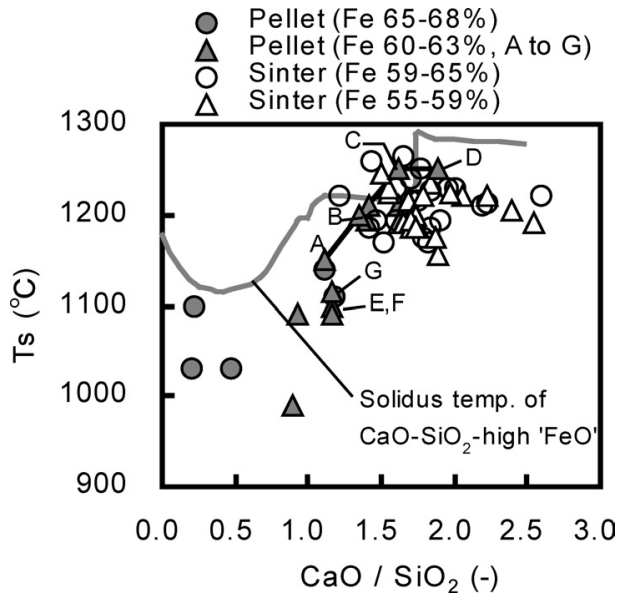

Fig. 6. Changes in Ts with basicity of sinter and pellets. A to $G$ are corresponding to pellets shown in Fig. 10 and Table 4. Estimated solidus temperature of $\mathrm{CaO}-\mathrm{SiO}_{2}-$ high ' $\mathrm{FeO}$ ' $\operatorname{slag}^{22)}$ was shown.

sinter and 70-80 mass $\%$ for pellets, respectively. Solidus temperature of simple $\mathrm{CaO}-\mathrm{SiO}_{2}$-high ' $\mathrm{FeO}$ ' slag was estimated from phase diagram as a function of basicity and shown in Fig. 6. Dependency of 'FeO' content on solidus temperature was insignificant in this slag at high ' $\mathrm{FeO}$ ' content above 50 mass $\%$. The relationship between solidus temperature and Ts will be discussed in the following chapter.

RTs is an important factor because it determines the quantity of forming melt containing ' $\mathrm{FeO}$ ' during softening-melting even in a constant chemical composition. RTs of pellets was lower than that of sinter (see Table 4), showing the different reduction behavior between sinter and pellets. Pellets are reduced in a topochemical fashion and readily form the metallic shell and show reduction retardation, resulting in low RTs. ${ }^{15)}$

Figure 7 shows the influences of $\mathrm{Al}_{2} \mathrm{O}_{3}$ and $\mathrm{MgO}$ on Ts. $\mathrm{Al}_{2} \mathrm{O}_{3}$ decreased $\mathrm{Ts}$, whereas $\mathrm{MgO}$ slightly increased, agreed with past investigations. ${ }^{4,12,16)}$ In both cases, the influence of the tendency with basicity was insignificant. High Ts tended to accompany with high RTs, showing that those two indices were linking each other.

\subsection{Influence of Pore Structure}

High reducibility enables to decrease quantity of forming melt during reduction as a result of decrease in $\mathrm{FeO}$ content of bulk oxide, resulting in the improvement of softeningmelting behavior even at a constant chemical composition of sinter. Figure 8 shows the relationship between R1000 and pore structure. Total porosity of sinter and pellets tended to enhance reducibility (Fig. 8(A)), however, a large scatter was found particularly in the case of sinter with low $\mathrm{Fe}$ content. This scatter is due to variety of pore structure and reducibility of constituting minerals. Closely evaluation of the influence of pore-size distribution in a constant level of total porosity and gangue content showed that porosity less than $15 \mu \mathrm{m}$ had an influence on reducibility (Fig. 8(B)). This result indicates that softening-melting behavior would be improved further by increasing porosity, in particular fine pores, even at a constant chemical composition. 
(A) $\mathrm{Al}_{2} \mathrm{O}_{3}$ content

Sinter $\left(\mathrm{SiO}_{2}=4-5 \%, \mathrm{MgO}=0.2-0.5 \%\right)$

Pellet $\left(\mathrm{SiO}_{2}=4.1-4.3 \%, \mathrm{MgO}=0 \%\right)$

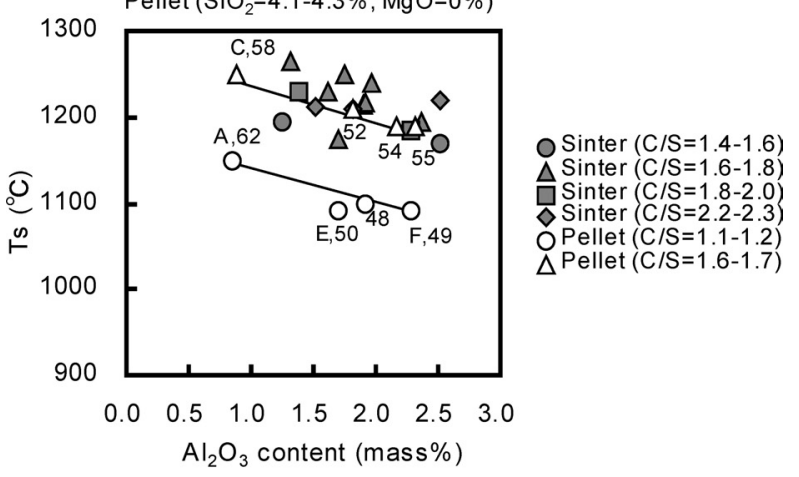

(B) MgO content

Sinter $\left(\mathrm{SiO}_{2}=4-6 \%, \mathrm{Al}_{2} \mathrm{O}_{3}=1.8-2.2 \%\right)$

Pellet $\left(\mathrm{SiO}_{2}=4.1-4.3 \%, \mathrm{Al}_{2} \mathrm{O}_{3}=1.6-1.9 \%\right)$

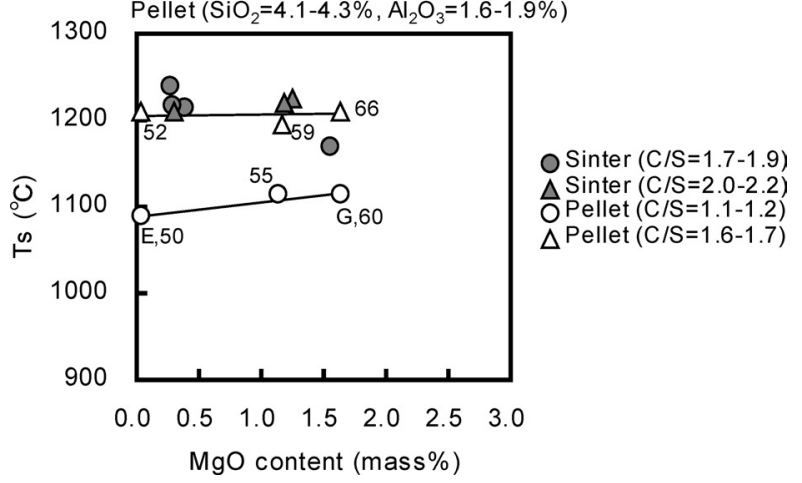

Fig. 7. Changes in Ts with (A) $\mathrm{Al}_{2} \mathrm{O}_{3}$ and (B) $\mathrm{MgO}$ contents in sinter and pellets. Numerical values are RTs. A to $\mathrm{G}$ are corresponding to pellets shown in Fig. 10 and Table 4.

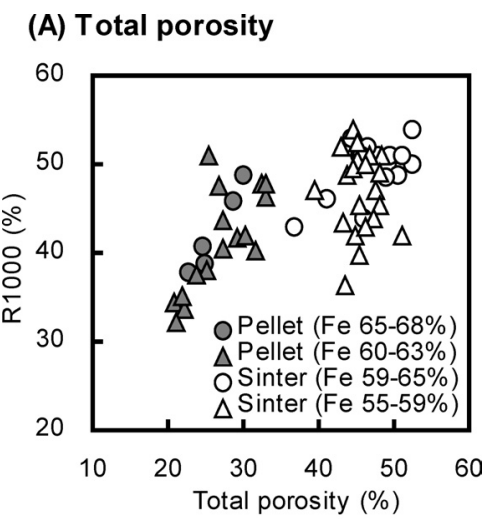

(B) Porosity below $15 \mu \mathrm{m}$

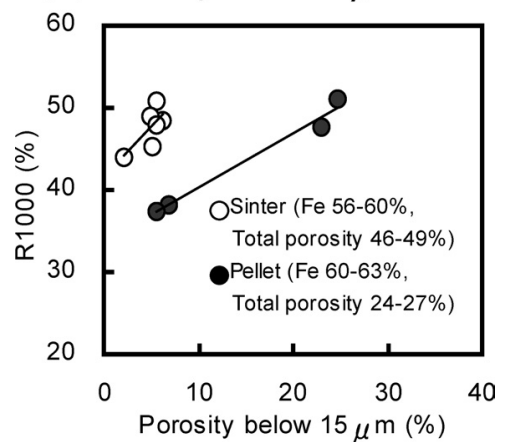

Fig. 8. Dependencies of total porosity (A) and porosity below $15 \mu \mathrm{m}$ (B) on R1000.

\section{Discussion}

\subsection{Factors Determining Dripping Temperature}

Dripping of molten iron takes place as a result of carburization of iron. The possible minimum temperature to form molten iron is $1145^{\circ} \mathrm{C}$ at 1.7 mass $\%$ carbon content. However 'dripping' of molten iron requires a certain extent of physical concentration of molten iron. The progress of the concentration of iron is influenced by properties of coexisting slag. If the part of melts crystallized with decreasing in 'FeO' content in slag, the crystallized phase impedes the physical contact of iron with solid carbon and the concentration of molten iron, resulting in a high-dripping temperature of molten iron. ${ }^{15,25)}$ As shown in Fig. 4, liquidus temperature of $\mathrm{CaO}-\mathrm{SiO}_{2}-\mathrm{Al}_{2} \mathrm{O}_{3}-{ }^{-} \mathrm{FeO}$ ' slag increased at basicity above 1.0 , corresponding to crystallization of solid $2 \mathrm{CaO} \cdot \mathrm{SiO}_{2}$ during reduction. Therefore the steep increase in $\mathrm{Td}$ found at high basicity related with an increase in solid phase impeding carburization.

On the other hand, Td was relatively high at basicity near 0.5 despite enough low liquidus temperature. The latest assessment of $\mathrm{CaO}-\mathrm{SiO}_{2}-\mathrm{Al}_{2} \mathrm{O}_{3}-10$ mass\% ' $\mathrm{FeO}$ ' slag by Jak et al. ${ }^{23)}$ showed liquidus temperature was less than $1300^{\circ} \mathrm{C}$ at basicity from 0.28 to 1.06 , allowing a fairly quantity of melt formation at low temperature below this temperature. Hino et al. ${ }^{26)}$ demonstrated melt formation process in blast furnace and evaluated two indices concerning the properties of forming melt, dripping temperature and hold-up. The former must be related with primary melt formation because it corresponded to eutectic temperatures of slag. The latter must be related with dripping of molten iron because it corresponds to directly nature of molten slag after heating up to $1400^{\circ} \mathrm{C}$. They observed that hold-up of $\mathrm{CaO}-\mathrm{SiO}_{2}-$ 20 mass $\% \mathrm{Al}_{2} \mathrm{O}_{3}-20$ mass $\%$ ' $\mathrm{FeO}$ ' slag increased with decreasing basicity in basicity below 1.0 , corresponding to the result of $\mathrm{Td}$ in the present study. Those results may be explained by fluidity of formed melt and smelting-reduction rate. Viscosity of $\mathrm{CaO}-\mathrm{SiO}_{2}-\mathrm{Al}_{2} \mathrm{O}_{3}-{ }^{6} \mathrm{FeO}$ ' slag $^{22)}$ and $\mathrm{CaO}-$ $\mathrm{SiO}_{2}-\mathrm{Al}_{2} \mathrm{O}_{3}-\mathrm{MgO}-{ }^{\prime} \mathrm{FeO}$ ' $\mathrm{slag}^{27)}$ is increased with decreasing basicity in basicity range below 1.3. In addition, Ohno et al. ${ }^{28)}$ found that carburization of reduced iron via molten slag was governed by smelting-reduction step, reduction of 'FeO' in slag by solid carbon, by in-situ observation. Smelting-reduction rate is influenced by the chemical composition of slag and that of low basicity slag is slow due to low activity of ' $\mathrm{FeO}$ ' compared to high basicity slag. ${ }^{29)}$ Thus high Td found at basicity less than 1.0 despite fairly quantity of melt mostly could be explained with high viscosity and low smelting-reduction rate.

The influence of $\mathrm{Al}_{2} \mathrm{O}_{3}$ and $\mathrm{MgO}$ found in the present study can be explained with this theory. As shown in Fig. 5(A), $\mathrm{Al}_{2} \mathrm{O}_{3}$ increases liquidus temperature of slag at low basicity $(\mathrm{C} / \mathrm{S}=1.1)$, agreed with an increase in hold-up at this basicity. ${ }^{26)}$ Viscosity tends to decrease with increases in $\mathrm{Al}_{2} \mathrm{O}_{3}$ at this basicity, however its extent is small. ${ }^{22,30)}$ In contrast, $\mathrm{Al}_{2} \mathrm{O}_{3}$ lowers liquidus temperature at high basicity above 1.4. Therefore the result of $\mathrm{Td}$ showing contrary influence of $\mathrm{Al}_{2} \mathrm{O}_{3}$ with basicity level was namely due to changes in liquidus temperature of slag.

Since the liquidus temperature of $\mathrm{CaO}-\mathrm{SiO}_{2}-\mathrm{Al}_{2} \mathrm{O}_{3}-$ $\mathrm{MgO}-' \mathrm{FeO}$ ' slag has been still unknown, indirect estima- 
tion of the system with using hold-up ${ }^{31)}$ was attempted. Hold-up changed in rather complex manner with ' $\mathrm{FeO}$ ' and basicity. Nevertheless, at a low 'FeO' content less than 20 mass $\%, \mathrm{MgO}$ lowered hold-up. In addition, viscosity of $\mathrm{CaO}-\mathrm{SiO}_{2}-10$ mass $\% \mathrm{Al}_{2} \mathrm{O}_{3}-5$ mass\% ' $\mathrm{FeO}$ ' slag at $1450^{\circ} \mathrm{C}$ decreased by adding $\mathrm{MgO}^{27)}$ This fact implies that $\mathrm{MgO}$ decreases the solid ratio in slag at low ' $\mathrm{FeO}$ ' region, resulting in low Td. However, it should be noted that this tendency is possible in the $\mathrm{MgO}$ content up to around 2.0 mass $\%$ because liquidus temperature of $\mathrm{CaO}-\mathrm{SiO}_{2}-$ 10 masss $\% \mathrm{Al}_{2} \mathrm{O}_{3}-\mathrm{MgO}$ slag shows a steep increase above this $\mathrm{MgO}$ content as shown in Fig. 5(B).

\subsection{Factors Determining Softening-Melting Tempera- ture}

As shown in Fig. 6, solidus temperatures of $\mathrm{CaO}-\mathrm{SiO}_{2}-$ high ' $\mathrm{FeO}$ ' slag showed a minimum at 0.5 in basicity and a maximum at 1.8 in basicity. This tendency was similar to that of solidus temperatures in $\mathrm{CaO}-\mathrm{SiO}_{2}-1$ mass $\%$ $\mathrm{Al}_{2} \mathrm{O}_{3}-$ ' $\mathrm{FeO}$ ' slag and $\mathrm{CaO}-\mathrm{SiO}_{2}-1$ mass $\% \mathrm{Al}_{2} \mathrm{O}_{3}-3$ mass $\%$ $\mathrm{MgO}-{ }^{\prime} \mathrm{FeO}$ ' slag measured by Shigaki et al. ${ }^{15}$ ) Those changes in solidus temperature were agreed with the results of Ts in the present study and other investigations. ${ }^{5,32)}$

As for the influence of $\mathrm{Al}_{2} \mathrm{O}_{3}$ and $\mathrm{MgO}, \mathrm{Al}_{2} \mathrm{O}_{3}$ lowered and $\mathrm{MgO}$ increased dripping temperature in Hino's experiments, ${ }^{31)}$ mostly exhibiting the changes in solidus temperature, which can explain the result of Ts in the present study. However, an extent of the influence of $\mathrm{Al}_{2} \mathrm{O}_{3}$ on Ts was larger than that of $\mathrm{MgO}$, could not fully explain with solidus temperature. Therefore to clarify the role of $\mathrm{MgO}$ on $\mathrm{Ts}$, the sinter sample with 1.87 basicity, $5.6 \mathrm{mass} \% \mathrm{SiO}_{2}$, 2.3 mass $\% \mathrm{Al}_{2} \mathrm{O}_{3}$ and 1.5 mass $\% \mathrm{MgO}$ was quenched at $1200^{\circ} \mathrm{C}$ by $\mathrm{N}_{2}$ during the reduction test under load. At this temperature, reduction degree was $74 \%$ and pressure drop had started to rise. Figure 9 shows a macro image of quenched sample. Chemical composition of constituting mineral phases was measured by EPMA and listed in Table 3. For the eutectic structure with fine participated wustite grains next to $2 \mathrm{CaO} \cdot \mathrm{SiO}_{2}$ phase, which seemed to relate with primary melt formation, area analysis was performed. Chemical composition of the structure was near the eutectic composition of $\mathrm{CaO} \cdot \mathrm{FeO} \cdot \mathrm{SiO}_{2}$ (Olivine)-2 $\mathrm{CaO} \cdot \mathrm{Al}_{2} \mathrm{O}_{3}$. $\mathrm{SiO}_{2}$ (Gehlenite)-'FeO'. Results clearly showed that $\mathrm{MgO}$ existed as wustite solid solution, whereas small quantity of $\mathrm{MgO}$ was found in the eutectic structure compared to $\mathrm{Al}_{2} \mathrm{O}_{3}$. This fact leads a conclusion that the influence of $\mathrm{MgO}$ on solidus temperature is rather small.

\subsection{Optimum Chemical Composition}

Results concluded that low-temperature dripping of molten iron could be achieved by namely optimization of chemical composition of sinter. In particular, basicity had large influence on dripping behavior and should be optimized as the first factor. Sinter with $1.0-1.5$ basicity had low $\mathrm{Td}$. The influences of $\mathrm{Al}_{2} \mathrm{O}_{3}$ and $\mathrm{MgO}$ varied with basicity. In the optimized basicity range (1.0-1.5), decreasing $\mathrm{Al}_{2} \mathrm{O}_{3}$ and increasing $\mathrm{MgO}$ would result in sinter with further low Td. Ts seemed to be not determined by chemical composition alone, however, above chemical composition would show fairy high Ts, resulting in high permeability of ore layer.

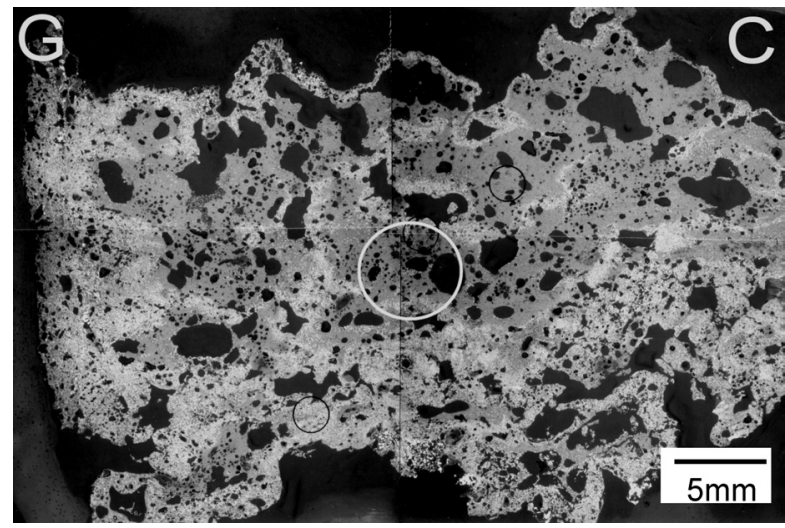

Fig. 9. Macro image of sinter layer during reduction quenched at $1200^{\circ} \mathrm{C}$. Circle represents analyzed area. G: Graphite crucible side, C: Central portion. Light phase and dark phase are metal and slag containing wustite, respectively. (Magnification $\times 5$ )

Edström et al. proposed 'high Fe-high MgO' opti-sinter made from high-grade magnetite ores and reported its superior reduction behavior. ${ }^{33)}$ Although sinter samples estimated in the present study was made from hematite and limonite ores, the optimized chemical composition of sinter in the present study was comparable as the composition proposed by Edström et al.

\subsection{Microstructures of Pellets and Sinter before Re- duction}

Figure 10 shows microstructures of pellets before reduction with different basicity (A to D), $\mathrm{Al}_{2} \mathrm{O}_{3}$ (A, E and $\mathrm{F}$ ) and $\mathrm{MgO}$ (E and $\mathrm{G})$. Table 4 shows measurement results of quantification of constituting minerals and reduction tests.

Glassy silicate as bonding phase of pellets turned into columnar SFCA (silico-ferrite of calcium and aluminium) with increasing basicity up to 1.62 . On the other hand, in the pellet with 1.88 basicity, SFCA was decreased and large size hematite and coexisting phase with SFCA and glassy silicate was found. This result means that fairly amount of melt formed during sintering and crystallized during cooling. Porosity decreased with basicity up to 1.35 due to an increase in melt and showed almost constant above this basicity.

These mineralogical changes led to a change in indirect reduction. A decrease in R1000 with basicity from 1.12 to 1.35 was caused by the decrease in porosity due to a penetration of melt into fine pores during induration. ${ }^{34)}$ In contrast, pellets with basicity above 1.35 represented high reducibility compared to that with 1.35 basicity, mostly due to changes in bonding phases from glassy silicate with low reducibility to SFCA with high reducibility.

A promotion of the formation of SFCA by $\mathrm{Al}_{2} \mathrm{O}_{3}{ }^{35)}$ was found (A, E, F), whereas a change in porosity was small. As a result, a change in $\mathrm{R} 1000$ with $\mathrm{Al}_{2} \mathrm{O}_{3}$ content was insignificant. It is known that $\mathrm{MgO}$ promotes a formation of magnetite, solid solution between $\mathrm{Fe}_{3} \mathrm{O}_{4}$ and $\mathrm{MgO} \cdot \mathrm{Fe}_{2} \mathrm{O}_{3}{ }^{36}$ ) and increases porosity due to suppression of melt formation during sintering. ${ }^{37)}$ In the present study, pellets with high $\mathrm{MgO}$ content showed high amount of magnetite phase coexisting re-oxidized hematite accompanied with high porosity $(\mathrm{E}, \mathrm{G})$. The increase in porosity promoted reduc- 
tion despite poor reducibility of magnetite than hematite.

These results conclude that mineralogical and structural changes with chemical composition influence on softening-melting behavior via a change in reducibility at indirect reduction stage as well. Hence, an inconsistency of Ts from the tendency of estimated solidus temperature was caused by the mineralogical and structural changes led by varying chemical composition.

Figure 11 shows microstructures of two typical sinter samples before reduction, one having chemical composition proposed in the present study, i.e. basicity less than 1.5 with low $\mathrm{Al}_{2} \mathrm{O}_{3}$ and high $\mathrm{MgO}$ content (S1) and the other having conventional chemical composition in plant (S2). Measurement results of microstructure and reduction tests
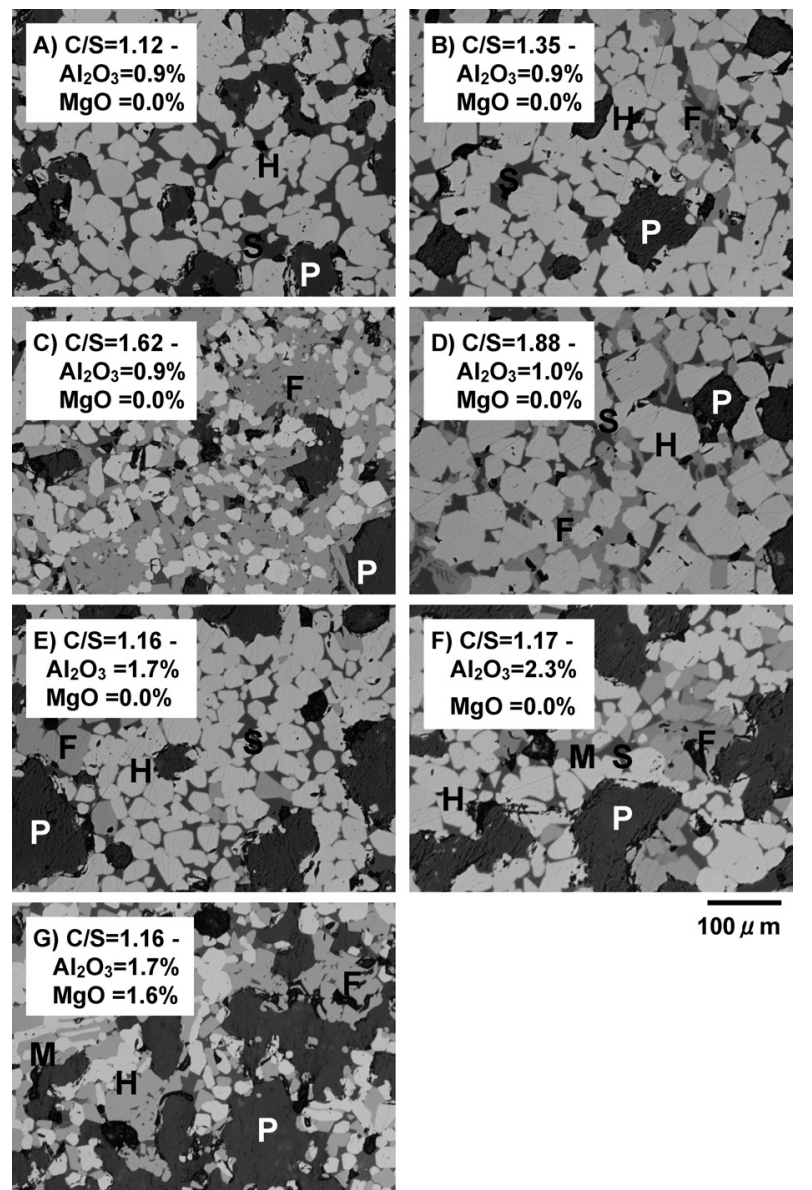

Fig. 10. Microstructures of pellets before reduction showing the influence of basicity in a constant $\mathrm{SiO}_{2}$ content (A to D), the influence of $\mathrm{Al}_{2} \mathrm{O}_{3}(\mathrm{~A}, \mathrm{E}, \mathrm{F})$ and the influence of $\mathrm{MgO}$ in a constant basicity (E, G). H: Hematite, M: Magnetite, F: SFCA, S: Glassy silicate, P: Pore. (Magnification $\times 200$ )
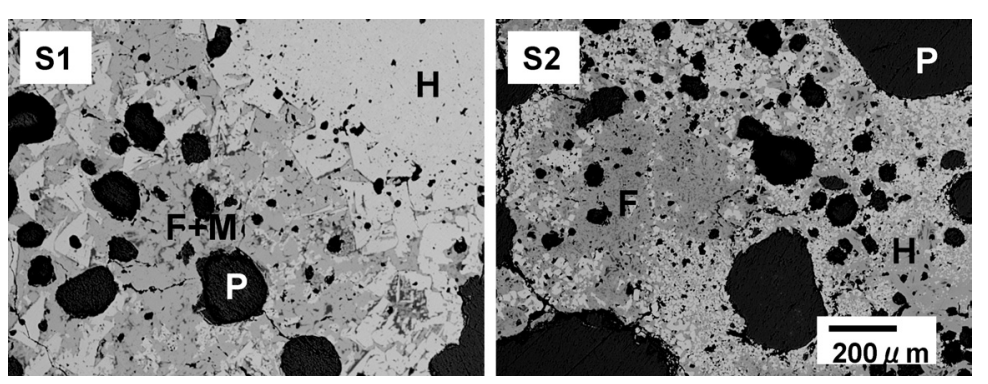

Fig. 11. Microstructures of sinter before reduction (magnification $\times 50$ ). H: Hematite, M: Magnetite, F: SFCA, P: Pore of both sinter samples were listed with their chemical compositions in Table 4 as well.

$\mathrm{S} 1$ had lower $\mathrm{Td}$ by $80^{\circ} \mathrm{C}$, simultaneously had higher Ts than $\mathrm{S} 2$, resulting in superior permeability. In producing $\mathrm{S} 1$, high rate of bonding agent to maintain strength of sinter resulted in high $\mathrm{FeO}$ content. S1 sinter consisted of many residual hematite ores and coexisting phase of SFCA and Magnetite, corresponding to blending condition and chemical composition, i.e. low $\mathrm{SiO}_{2}$ and low $\mathrm{CaO}$ content with high $\mathrm{FeO}$ content. This chemical composition led to high total porosity of S1. Reducibility was inferior mostly due to high magnetite content and coarse residual ores with less porosity, however, Ts was higher than that of S2 as a result of optimization of chemical composition.

\subsection{Influence of Sinter Mineralogy}

It was revealed that chemical composition and pore structure of sinter were dominant factors determining softening-melting behavior. However, sinter mineralogy, i.e. size and distribution of constituting minerals is considered as the third factor influencing Ts because it relates with reduction degree closely. Maeda et al. ${ }^{17)}$ found that high-temperature reduction of natural ores depended on their quantity and distribution of gangue minerals and porosity. The amount of gangue minerals and their homogeneous distribution in ores enhanced formation of $\mathrm{FeO} \cdot 2 \mathrm{SiO}_{2}$ during reduction, resulting in a reduction retardation at $1200^{\circ} \mathrm{C}$. However, this finding is corresponding to the reduction of lumpy ores or residual ores in sintered ore structure. The influence of sinter mineralogy, depending on chemical composition, ore mineralogy and sintering condition, on hightemperature reduction is still unknown.

Figure 12 shows the results of R1200 of two kinds of samples, one natural ores without assimilation with $\mathrm{CaO}$ demonstrating residual ores in sinter structure $(\mathrm{A})$ and the other sintered sample after assimilation with $\mathrm{CaO}$ demonstrating sinter itself (B), as a function of Fe content of source ores after dehydration. Numerical values in the figures are porosity before reduction. Porosity of (A) samples were measured after dehydration of natural ores at $1300^{\circ} \mathrm{C}$ for $5 \mathrm{~min}$. Figure 13 shows microstructures of sintered sample after assimilation with $\mathrm{CaO}$, attached with area fraction of residual ores and types of bonding phases.

Results of both natural ores and sintered ores could be explained with differences of Fe content and pore structure. A significant retardation of reduction at temperatures near $1100^{\circ} \mathrm{C}$ was observed in the reduction of ores containing low $\mathrm{Fe}$ content, corresponding to solidus temperature of $1083^{\circ} \mathrm{C}$, eutectic of $\mathrm{SiO}_{2}-2 \mathrm{FeO} \cdot \mathrm{SiO}_{2}-2 \mathrm{FeO} \cdot 2 \mathrm{Al}_{2} \mathrm{O}_{3}$. $5 \mathrm{SiO}_{2}$, in $\mathrm{SiO}_{2}-\mathrm{Al}_{2} \mathrm{O}_{3}-$ 'FeO' slag. In addition, wustite grain 
(A) Before assimilation with $\mathrm{CaO}$

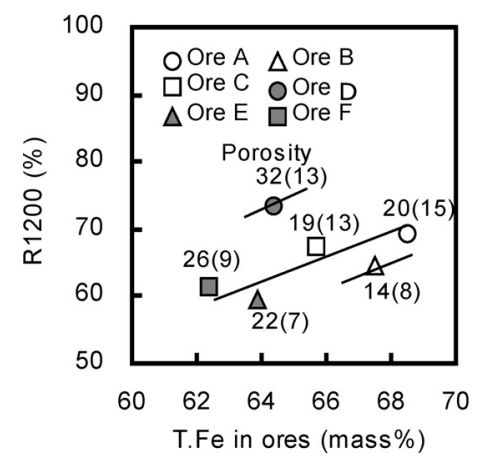

(B) After assimilation with $\mathrm{CaO}$

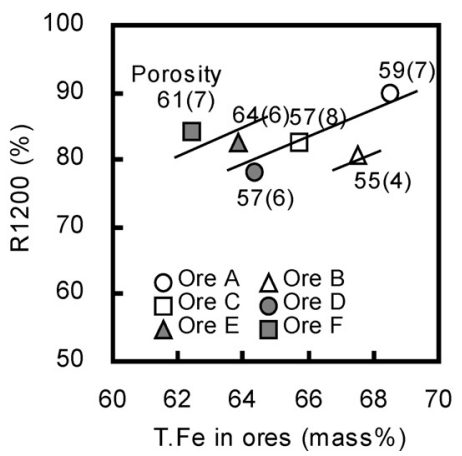

Fig. 12. Results of R1200 of natural ore samples (A) and of sintered sample (B) as a function of Fe content in source ores after dehydration. Numerical values are total porosity and ( $-15 \mu \mathrm{m}$ porosity).
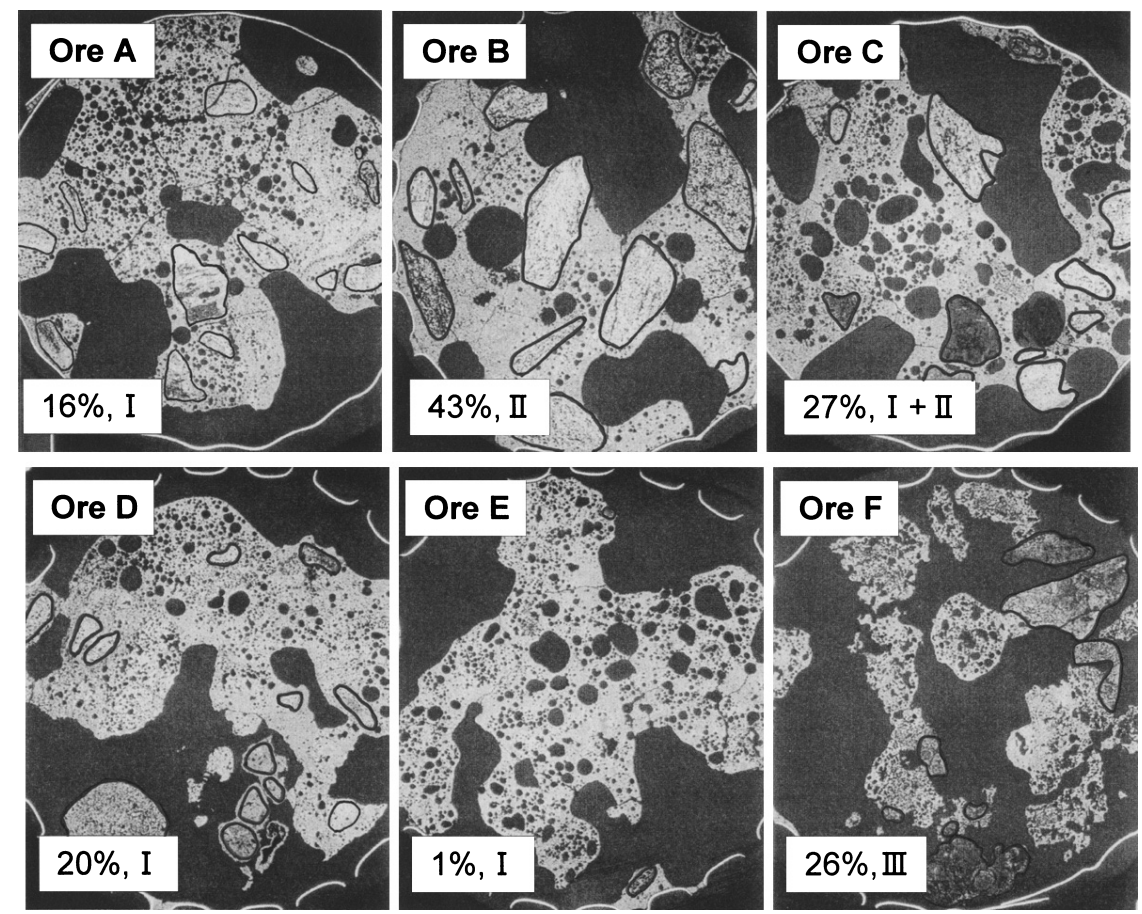

Fig. 13. Macro images of sintered ores before reduction (Magnification $\times 5$ ). $\square$ indicates residual ores. Numerical values are area fraction of residual ores and Type of minerals after assimilation. I: 'Primary hematite and SFCA', II: 'SFCA', III: 'Primary hematite+ glassy silicates' and 'Primary hematite + SFCA'.

size after pre-reduction was observed to have influence on reducibility. Reduced iron showed massive structure sintering each other in the reduction of Ore B, whereas reduced iron formed fine network in the reduction of other ores. Therefore Ore B seemed to have low reducibility at high temperature despite its low gangue content due to its dense structure and large grain size.

On the other hand, it was noteworthy that some of ores with low Fe content showed high reducibility after sintering. These facts lead the conclusion that assimilation control of iron ores in sintering process could enhance reducibility, resulting in further improvement of softeningmelting behavior even at a constant chemical composition of sinter thorough changes in structure of pores and minerals.

Furthermore, types of bonding phase depended on ore types. However, the influence of types of bonding phases on softening-melting behavior is still unknown, thus fundamental study is necessary to reveal the influence to counter- ing the deterioration of quality of iron ore sources.

\section{Conclusions}

To discuss sinter condition for an innovative compact blast furnace, reduction behavior of sinter and pellets with extensive range of chemical composition was measured with reduction test under load. In particular, conditions for a low-temperature drip of molten iron with high reducibility of iron ore sinter were discussed. Following conclusions were derived.

(1) Dripping temperature of molten iron was largely influenced by chemical composition of sinter. Basicity was found to have dominant influence on dripping temperature and should be optimized first. Sinter and pellets with basicity ranged 1.0-1.5 represented low-temperature drip, which was related with low liquidus temperature, low viscosity and fast smelting-reduction of slag. The influences of $\mathrm{Al}_{2} \mathrm{O}_{3}$ and $\mathrm{MgO}$ were rather complex and varied with basicity 
range. Further decrease in dripping temperature was achieved by decreasing $\mathrm{Al}_{2} \mathrm{O}_{3}$ content and increasing $\mathrm{MgO}$ content in sinter with $1.0-1.5$ basicity.

(2) Softening-melting behavior depended on chemical composition, pore structure and sinter mineralogy. Softening-melting temperature was determined by solidus temperature of slag containing high $\mathrm{FeO}$ content and reducibility. Lowing $\mathrm{Al}_{2} \mathrm{O}_{3}$ content contributed to an increase in softening-melting temperature. Increasing porosity of sinter, particularly fine pores, could enhance reducibility.

(3) Optimized sinter, containing 1.0-1.5 basicity, low $\mathrm{Al}_{2} \mathrm{O}_{3}$ and high $\mathrm{MgO}$ content, was proposed. A decrease in dripping temperature by $80^{\circ} \mathrm{C}$ with fairly high permeability of sinter layer could be confirmed compared to conventional sinter.

(4) Sinter mineralogy arisen from iron ore nature influenced on reducibility at high temperatures. This influence involved with assimilation extent, grain size of hematite and gangue distribution. Hence, further improvement of softening-melting behavior based on sinter mineralogy would be possible even at constant chemical composition of sinter, if selection of ores or controlling sinter operation were managed.

\section{Acknowledgments}

This work was supported by the research project on 'Science and Technology of Innovative Ironmaking for aiming at Energy Half Consumption,' from Ministry of Education, Culture, Sports, Science and Technology of Japan. The authors gratefully acknowledge Dr. K. Yamaguchi (formerly with Nippon Steel Corporation now with Tohoku Economic Federation) for many suggestions.

\section{REFERENCES}

1) K. Ono, Y. Hida, A. Shigemi and K. Kodama: Tetsu-to-Hagané, 61 (1975), 777.

2) K. Narita, M. Maekawa, M. Kitamura and H. Kanayama: Trans. Iron Steel Inst. Jpn., 19 (1979), 766.

3) M. Hatano, T. Miyazaki and Y. Iwanaga: Proc. of 41 st Ironmaking Conf., ISS, Warrendale, PA, (1982), 61.

4) H. Kokubu, S. Taguchi, N. Tsuchiya, A. Sasaki, A. Kato and K. Okumura: McMaster Symposium 12, ed. by W. K. Lu, McMaster University, Hamilton, (1984), 334.

5) P. Barnaba: Ironmaking Steelmaking, 12 (1985), 53.

6) R. Burgstrand: 55th Ironmaking Conf. Proc., ISS, Warrendale, PA, (1996), 493.

7) K. One, T. Kawaguchi, M. Hoshi, Y. Hadano and T. Umezaki: Rev. Métall., Cah. Int. Tech., (1998), March, 321.

8) Y.Iwanaga: Ironmaking Steelmaking, 16 (1989), 392.

9) T. Miyazaki, T. Shimoda, Y. Iwanaga and C. Yamagata: McMaster Symposium 12, ed. by W. K. Lu, McMaster University, Hamilton, (1984), 178.
10) H. Nishio, Y. Yamaoka, K. Nakano, H. Yanaka and K. Shiohara: Proc. of 41st Ironmaking Conf., ISS, Warrendale, PA, (1982), 90.

11) K. Yamaguchi, H. Ueno, T. Kawaguchi, S. Matsunaga, H. Oda and S. Amano: ISIJ Int., 34 (1994), 964.

12) T. Tsutsumi, Z. Wang, Y. Sasaki, Y. Kashiwaya, K. Ishii and N. Konno: Tetsu-to-Hagané, 84 (1998), 477.

13) H. W. Gudenau, K. Kreibich and Y. Nomiya: Stahl Eisen, 99 (1979), 1204.

14) V. J. Ritz, H. A. Kortman and K. Koch: 57th Ironmaking Conf. Proc., ISS, Warrendale, PA, (1998), 1635.

15) I. Shigaki, S. Shirouchi, K. Tokutake and N. Hasegawa: ISIJ Int., 30 (1990), 199.

16) T. Uenaka, K. Aketa, S. Hachiya and R. Hori: McMaster Symposium 12, ed. by W. K. Lu, McMaster University, Hamilton, (1984), 207.

17) T. Maeda, Y. Fukumoto and M. Shimizu: Tetsu-to-Hagané, 87 (2001), 327.

18) S. Kasama, T. Haga, T. Inazumi and T. Sato: Tetsu-to-Hagané, 83 (1997), 109.

19) Y. Hosotani, K. Yamaguchi, T. Orimoto, K. Higuchi, T. Kawaguchi and H. Goto: Tetsu-to-Hagané, 83 (1997), 97.

20) T. Shiota, M. Naito, K. Yamaguchi, Y. Hida and Y. Hayashi: CAMPISIJ, 1 (1988), 51.

21) A. Tayama, Y. Shimomura, K. Kushima, T. Nakata and K. Fujita: Proc. of 39th Ironmaking Conf., ISS, Warrendale, PA, (1980), 390.

22) Slag Atlas 2nd Ed., ed. by VDEh, Verlag Stahleisen GmbH, Düsseldorf, (1995).

23) E. Jak and P. C. Hayes: Science and Technology of Innovative Ironmaking for aiming at Energy Half Consumption, ISIJ, Tokyo, (2003), 169.

24) T. Bakker and R. H. Heerema: 57th Ironmaking Conf. Proc., ISS, Warrendale, PA, (1998), 1597.

25) S. Kondo and K. Ishii: Tetsu-to-Hagané, 70 (1984), A1.

26) M. Hino, T. Nagasaka, A. Katsumata, K. Higuchi, K. Yamaguchi and N. Konno: Metall. Mater. Trans. B, 30B (1999), 671.

27) Y. S. Lee, J. R. Kim, S. H. Yi and D. J. Min: Proc. VII Int. Conf. on Molten Slags Fluxes and Salts, The Southern African Institute of Mining and Metallurgy, Johannesburg, (2004), 225.

28) K. Ohno, T. Nagasaka and M. Hino: Steel Res., 74 (2003), 5.

29) T. Enaka, Y. Uchida, H. Hasegawa, M. Naito, A. McLean and M. Iwase: Scand. J. Metall., 30 (2001), 168.

30) A. Kondratiev and E. Jak: Proc. VII Int. Conf. on Molten Slags Fluxes and Salts, The Southern African Institute of Mining and Metallurgy, Johannesburg, (2004), 141.

31) M. Hino, A. Kumano, K. Shimizu and K. Shimizuno and T. Nagasaka: Proc. of the Yazawa Int. Symp.-Vol. 1, ed. by F. Kongoli, K. Itagaki, C. Yamauchi and H. Y. Sohn, TMS, Warrendale, PA, (2003), 861.

32) P. F. Nogueira and R. J. Fruehan: Iron Steelmaker, 30 (2003), July, 29.

33) J. O. Edström and S. Ajmal: Proc. of the 6th Int. Iron and Steel Cong., ISIJ, Tokyo, (1990), 71.

34) M. Nakamoto, H. Ono-Nakazato, H. Kawabata and T. Usui: Tetsu-toHagané, 90 (2004), 1.

35) P. R. Dawson, J. Ostwald and K. M. Hayes: Trans. Inst. Min. Metall. C, 94C (1985), C71.

36) S. C. Panigraphy, P. Verstraeten and J. Dilewijns: Metall. Trans. B, 15B (1984), 23.

37) O. Tsuchiya, T. Sugiyama, M. Onoda and I. Fujita: Tetsu-to-Hagané, 66 (1980), 1840. 